\title{
The Effect of Air Temperature on Growth of Eight Herb Species
}

\author{
Leiv M. Mortensen \\ Department of Plant Science, The Norwegian University of Life Sciences, Ås, Norway \\ Email: lei-mo@online.no
}

Received 16 March 2014; revised 15 April 2014; accepted 23 April 2014

Copyright (C) 2014 by author and Scientific Research Publishing Inc.

This work is licensed under the Creative Commons Attribution International License (CC BY).

http://creativecommons.org/licenses/by/4.0/

(c) (i) Open Access

\begin{abstract}
The effect of different constant air temperatures $\left(18^{\circ} \mathrm{C}, 21^{\circ} \mathrm{C}, 24^{\circ} \mathrm{C}\right.$ and $\left.27^{\circ} \mathrm{C}\right)$ and variable temperatures $\left(24^{\circ} \mathrm{C} / 18^{\circ} \mathrm{C}\right.$ and $27^{\circ} \mathrm{C} / 15^{\circ} \mathrm{C}$ in $12 \mathrm{~h} / 12 \mathrm{~h}$ periods) on basil, sage, thyme, lemon balm, cilantro, rosemary, oregano and rocket was studied. Supplementary lighting was given $16 \mathrm{~h} \cdot \mathrm{day}^{-1}$ at a photon flux density (PFD) of $150 \mu \mathrm{mol} \cdot \mathrm{m}^{-2} \cdot \mathrm{s}^{-1}$ (corresponding to $8.6 \mathrm{~mol} \cdot \mathrm{m}^{-2} \cdot$ day $^{-1}$ photosynthetic active radiation [PAR]). Including daylight the PAR was $29.6 \pm 6.9 \mathrm{~mol} \cdot \mathrm{m}^{-2} \cdot \mathrm{day}^{-1}$ as a mean during the experimental period. Increasing the temperature from $18^{\circ} \mathrm{C}$ to $27^{\circ} \mathrm{C}$ increased the fresh weight in basil $(106 \%)$, sage $(95 \%)$, rosemary $(126 \%)$ and rocket $(62 \%)$, while an increase from $18^{\circ} \mathrm{C}$ to $24^{\circ} \mathrm{C}$ increased the weight in lemon balm (78\%), cilantro (41\%), oregano $(40 \%)$ and thyme $(58 \%)$. For the last four species the fresh weight was unaffected by a further increase to $27^{\circ} \mathrm{C}$. No significant difference was found between the $24^{\circ} \mathrm{C} / 18^{\circ} \mathrm{C}$ and $27^{\circ} \mathrm{C} / 15^{\circ} \mathrm{C}$ treatments. These treatments gave a mean temperature of about $21^{\circ} \mathrm{C}$, and no significant differences were found between these treatments and the constant $21^{\circ} \mathrm{C}$ treatment. The plant height generally increased in the same proportion as the fresh weight increased in the different species. No differences were visually observed between the treatments after two weeks under indoor conditions. All species remained green except cilantro and rocket, for which some leaf yellowing took place. A simple test indicated that the flavour increased with increasing temperature (from $18^{\circ} \mathrm{C}$ to $27^{\circ} \mathrm{C}$ ) in all species except cilantro.
\end{abstract}

\section{Keywords}

Air Temperature, Basil, Cilantro, Growth, Lemon Balm, Oregano, Rocket, Rosemary, Sage, Thyme

\section{Introduction}

Relatively few studies have been done on the effect of temperature on herbs. Relatively low temperatures of 13 to $18^{\circ} \mathrm{C}$ have been recommended for herbs [1] [2], and temperatures below $20^{\circ} \mathrm{C}$ are used in the greenhouse production of herbs in Norway. General experience of the effects of climate on plant production in greenhouses 
suggests that such a practice is strange. Usually $\mathrm{CO}_{2}$ enrichment is applied in greenhouses, but the literature on herbs suggests that this factor is often neglected. Knowing that high temperatures in combination with high $\mathrm{CO}_{2}$ concentrations might significantly increase photosynthesis in plants [3] an experiment with different herb species was recently carried out [4]. This study included mean temperatures ranging from $19.0^{\circ} \mathrm{C}$ to $22.5^{\circ} \mathrm{C}$ and showed a stimulation of growth with increased temperature. However, with the belief that higher temperatures than this could be beneficial for an experiment including temperatures ranging from $18^{\circ} \mathrm{C}$ to $27^{\circ} \mathrm{C}$ that was carried out in order to see if the productivity of herbs could be significantly increased. Combinations of high day and low night temperatures were included, bearing in mind that such a climate control would save energy [5] [6].

\section{Materials and Methods}

Eight herb species—basil (Ocimum basilicum), sage (Salvia officinalis), thyme (Thymus vulgaris), lemon balm (Melissa officinalis), cilantro (Coriandrum sativum), rosemary (Rosmarinus officinalis), oregano (Origanum vulgare) and rocket (Eruca vesicaria) —were sown in $11 \mathrm{~cm}$ pots by a drill at Gjennestad Gardener School and were germinated before start of the experiment. Six pots of each species were placed in six climate controlled growth chambers that were placed in a greenhouse compartment at Bioforsk Særheim, Norway (latitude $59^{\circ}$ north). Four different constant air temperature treatments were applied: $18^{\circ} \mathrm{C}, 21^{\circ} \mathrm{C}, 24^{\circ} \mathrm{C}$ and $27^{\circ} \mathrm{C}$, resulting in $18.2^{\circ} \mathrm{C}, 20.7^{\circ} \mathrm{C}, 23.5^{\circ} \mathrm{C}$ and $26.1^{\circ} \mathrm{C}$ as means for the 22-day experimental period. During the dark period the temperature decreased by $1^{\circ} \mathrm{C}$ to $2^{\circ} \mathrm{C}$. In addition two variable temperature treatments were given: $24 / 18\left(20.4^{\circ} \mathrm{C}\right.$ as a mean) and $27^{\circ} \mathrm{C} / 15^{\circ} \mathrm{C}\left(20.7^{\circ} \mathrm{C}\right.$ as a mean) in $12 \mathrm{~h} / 12 \mathrm{~h}$ periods (Figure 1$)$. Supplementary lighting was given $16 \mathrm{~h} \cdot$ day $^{-1}$ at a photon flux density (PFD) of $150 \mu \mathrm{mol} \cdot \mathrm{m}^{-2} \cdot \mathrm{s}^{-1}$ (corresponding to $8.6 \mathrm{~mol} \cdot \mathrm{m}^{-2} \cdot \mathrm{day}^{-1} \mathrm{PAR}$ ) by means of high pressure sodium lamps (Philips SON/T). The light was measured by a Lambda LI-185B instrument with a quantum sensor above the plants. The dark period was $8 \mathrm{~h} \cdot \mathrm{day}^{-1}$, and the $12 \mathrm{~h}$ low temperature treatment started two hours before and ended two hours after the dark period. Including daylight as measured at the Meteorological Station of Bioforsk Særheim (www.bioforsk.no, Agricultural Meteorological Service), the PAR was $29.6 \pm 6.9 \mathrm{~mol} \cdot \mathrm{m}^{-2} \cdot$ day $^{-1}$ as a mean during the experimental period (27 April until 19 May) (Figure 2). The daylight was decreased $50 \%$ due to reduction by the greenhouse and growth chamber constructions. The $\mathrm{CO}_{2}$ concentration was $880 \pm 40 \mu \mathrm{mol} \cdot \mathrm{mol}^{-1}$ as measured by an infrared gas analyser, and the relative humidity was $80 \% \pm 5 \%$. Because of high growth rates five of the species were harvested after 15 days (on 12 May) while the three remaining species (oregano, thyme and rosemary) were harvested after 22 days (on 19 May). The fresh weight and plant height of four pots per treatment and per species were recorded. Two pots per treatment and per species were placed in a room under simulated indoor conditions at a temperature of $22^{\circ} \mathrm{C} \pm 1{ }^{\circ} \mathrm{C}$, a relative

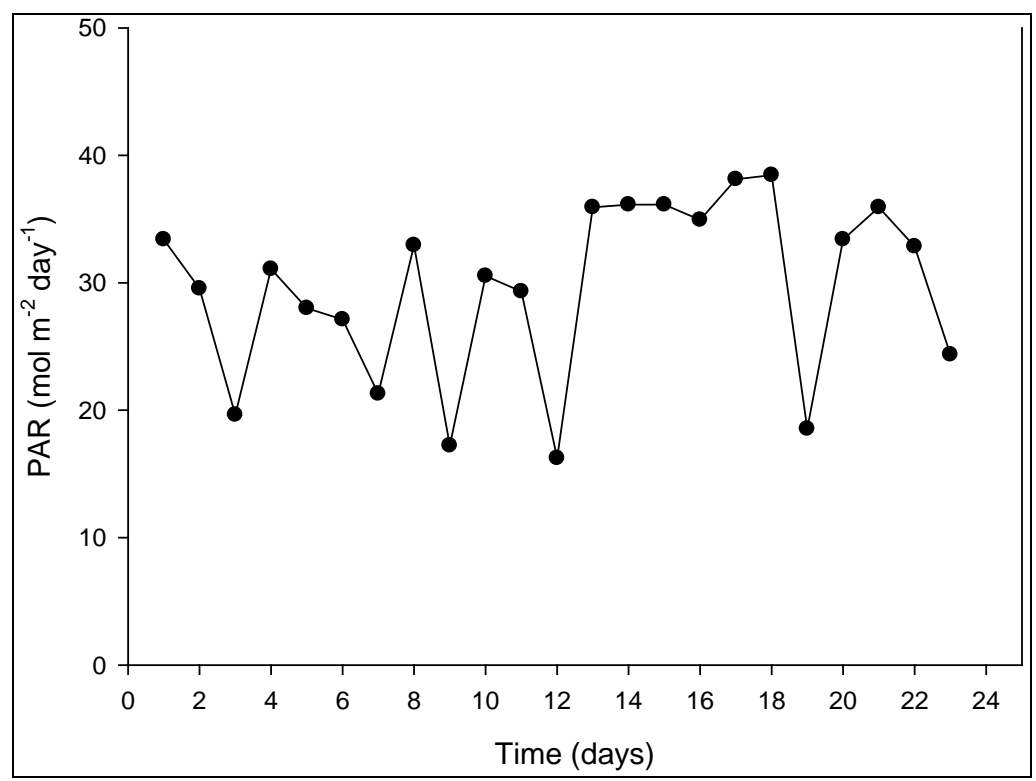

Figure 1. The PAR contributed by daylight during the experimental period from 27 April until 19 May. 


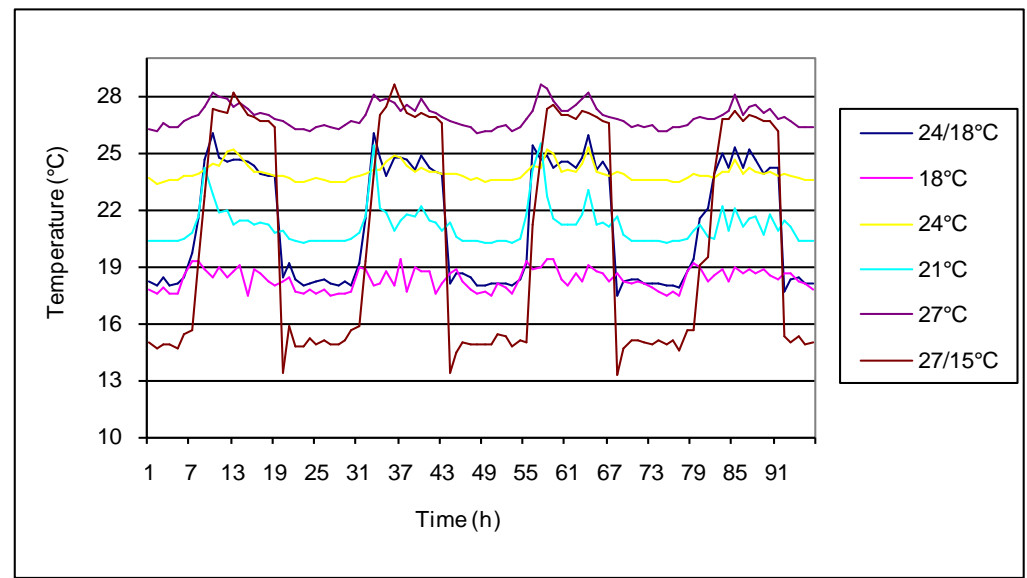

Figure 2. The air temperature recorded during four days in the six different treatments.

humidity of $50 \% \pm 5 \%$ and a PFD of $15 \mu \mathrm{mol} \cdot \mathrm{m}^{-2} \cdot \mathrm{s}^{-1}$, applied $12 \mathrm{~h} \cdot$ day $^{-1}$ by cool white fluorescent tubes (Philips TL33). The visual appearance of the plants was described after 14 days in the test room. Finally, a simple test was carried out by two people in order to get an indication of the relative flavour of the herbs at $18^{\circ} \mathrm{C}, 24^{\circ} \mathrm{C}$ and $27^{\circ} \mathrm{C}$ treatments.

The data were analysed by means of the Duncan multiple range test at $\mathrm{p}=0.05$ level with pots as replicates.

\section{Results}

Increasing the temperature from $18^{\circ} \mathrm{C}$ up to $27^{\circ} \mathrm{C}$ increased the fresh weight in basil (106\%), sage (95\%), rosemary (126\%) and rocket (62\%) (Table 1). An increase from $18^{\circ} \mathrm{C}$ to $24^{\circ} \mathrm{C}$ increased the weight in lemon balm (78\%), cilantro (41\%), oregano (40\%) and thyme (58\%), while a further increase to $27^{\circ} \mathrm{C}$ had no effect (Table 1). No significant difference was found between the $24^{\circ} \mathrm{C} / 18^{\circ} \mathrm{C}$ and $27^{\circ} \mathrm{C} / 15^{\circ} \mathrm{C}$ treatments. These treatments had about the same average temperature as the constant $21^{\circ} \mathrm{C}$ treatment, and no significant differences on the fresh weight were found between these treatments. The plant height generally increased in the same proportion as the fresh weight in the different species (Table 2). Calculating the fresh weight per $\mathrm{cm}$ height made it clear that there were no significant differences between the different treatments in all species (results not presented). After two weeks under simulated indoor conditions no differences between the treatments could be visually observed on the plants that remained green, with the exceptions of cilantro and rocket, for which leaf yellowing had taken place in all treatments (results not presented). A simple test indicated that increasing the temperature from 18 to $24^{\circ} \mathrm{C}$ to $27^{\circ} \mathrm{C}$ strongly increased the flavour of all species except cilantro, which retained a mild flavour.

\section{Discussion}

The results were quite surprising given the commercial practise of growing herbs at temperatures below $20^{\circ} \mathrm{C}$. A substantial increase in the fresh weights of all eight herbs (ranging from 40 to 126\%) was found to correspond to an increase in temperature from $18^{\circ} \mathrm{C}$ to $24^{\circ} \mathrm{C}$ or $27^{\circ} \mathrm{C}$. Previous results with sage have shown increased growth up to $30^{\circ} \mathrm{C}$ when growing the plants at a PAR level of $34.7 \mathrm{~mol} \cdot \mathrm{m}^{-2} \cdot$ day $^{-1}$ [2], which is in accordance with the present results. In basil it was found that $30^{\circ} \mathrm{C} / 12^{\circ} \mathrm{C}$ (mean temperature $24^{\circ} \mathrm{C}$ ) gave a higher fresh weight than $24^{\circ} \mathrm{C} / 12^{\circ} \mathrm{C}$ (mean temperature $20^{\circ} \mathrm{C}$ ) [7]. When applying a low PAR of 2.9 to $3.8 \mathrm{~mol} \cdot \mathrm{m}^{-2} \cdot$ day $^{-1}$, it was not surprising that the growth of herbs was found to be better at $15^{\circ} \mathrm{C} / 10^{\circ} \mathrm{C}$ than at $20^{\circ} \mathrm{C} / 15^{\circ} \mathrm{C}$ day/night temperature [8]. By increasing the PAR level, the temperature for maximum growth will increase. It is important to be aware that high-temperature production $\left(24^{\circ} \mathrm{C}\right.$ to $\left.27^{\circ} \mathrm{C}\right)$ in herbs requires PAR levels of at least 15 to $20 \mathrm{~mol} \cdot \mathrm{m}^{-2} \cdot \mathrm{day}^{-1}$, similar to what was found for miniature roses at higher temperatures [9]. When plants are grown at high $\mathrm{CO}_{2}$ concentrations the optimum temperature for growth is likely to increase [3], and they will also be protected against high-temperature damage [10]. The present results show that the mean temperature determined the growth rate of the herb species, since both a constant temperature of $21^{\circ} \mathrm{C}$ and a mean temperature of $21^{\circ} \mathrm{C}$ achieved with variable temperature treatments of $27^{\circ} \mathrm{C} / 15^{\circ} \mathrm{C}$ or $24^{\circ} \mathrm{C} / 18^{\circ} \mathrm{C}$ gave the same fresh weight. This is in 
Table 1. Fresh weight per pot (g) as affected by different temperature treatments in eight different herbs. Values followed by different letters are significantly different according to Duncan's multiple range test at $\mathrm{p}=0.05$ level.

\begin{tabular}{|c|c|c|c|c|c|c|}
\hline \multirow[b]{2}{*}{ Species } & \multicolumn{6}{|c|}{ Temperature $\left({ }^{\circ} \mathrm{C}\right)$} \\
\hline & 18 & 21 & 24 & 27 & $27 / 15$ & $24 / 18$ \\
\hline Sage & $37 d$ & $50 c$ & $62 b$ & $72 a$ & $54 \mathrm{bc}$ & $56 \mathrm{bc}$ \\
\hline Lemon balm & $18 \mathrm{~b}$ & $22 b$ & $32 a$ & $37 a$ & $20 \mathrm{~b}$ & $24 \mathrm{~b}$ \\
\hline Cilantro & $63 c$ & $74 \mathrm{~b}$ & $89 a$ & $88 a$ & $85 a$ & 81ab \\
\hline Rocket & $55 \mathrm{c}$ & $53 c$ & $71 b$ & $89 a$ & $74 \mathrm{~b}$ & 64bc \\
\hline Basil & $52 \mathrm{~d}$ & $63 \mathrm{~cd}$ & $85 b$ & $107 a$ & $82 b$ & $68 c$ \\
\hline Rosemary & $19 d$ & $23 \mathrm{~cd}$ & $31 b$ & $43 a$ & $30 \mathrm{bc}$ & $30 \mathrm{bc}$ \\
\hline Oregano & $45 c$ & 53bc & 63ab & $68 a$ & 59ab & $59 a b$ \\
\hline Thyme & $45 b$ & $44 \mathrm{~b}$ & $71 \mathrm{a}$ & $76 a$ & $70 a$ & $56 \mathrm{~b}$ \\
\hline Mean & $42 \mathrm{~d}$ & 48cd & 63ab & $72 a$ & $59 b$ & $55 \mathrm{bc}$ \\
\hline
\end{tabular}

Table 2. Plant height $(\mathrm{cm})$ as affected by different temperature treatments in eight different herbs. Values followed by different letters are significantly different according to Duncan's multiple range test at $\mathrm{p}=0.05$ level.

\begin{tabular}{|c|c|c|c|c|c|c|}
\hline \multirow[b]{2}{*}{ Species } & \multicolumn{6}{|c|}{ Temperature $\left({ }^{\circ} \mathrm{C}\right)$} \\
\hline & 18 & 21 & 24 & 27 & $27 / 15$ & $24 / 18$ \\
\hline Sage & 9c & $13 b$ & $17 \mathrm{a}$ & $18 \mathrm{a}$ & $14 \mathrm{~b}$ & $14 \mathrm{~b}$ \\
\hline Lemon balm & $7 d$ & $9 c$ & $10 \mathrm{~b}$ & $12 a$ & $8 c$ & $9 c$ \\
\hline Cilantro & $17 b$ & $17 b$ & $20 \mathrm{a}$ & $19 a b$ & $21 \mathrm{a}$ & 19a \\
\hline Rocket & $8 b$ & $10 \mathrm{ab}$ & $10 \mathrm{ab}$ & $12 \mathrm{a}$ & $12 \mathrm{a}$ & $10 \mathrm{ab}$ \\
\hline Basil & $8 e$ & 9de & $14 \mathrm{~b}$ & $18 \mathrm{a}$ & $13 c$ & $10 \mathrm{~d}$ \\
\hline Rosemary & $4 e$ & 5de & $8 a b$ & $9 a$ & $7 \mathrm{bc}$ & $6 \mathrm{~cd}$ \\
\hline Oregano & 7c & $8 b$ & $11 \mathrm{a}$ & $11 \mathrm{a}$ & $11 \mathrm{a}$ & $9 b$ \\
\hline Thyme & $9 b$ & $9 b$ & $11 b$ & $11 b$ & $12 b$ & $15 a$ \\
\hline Mean & $8 d$ & 10cd & 13ab & $14 a$ & $12 \mathrm{ab}$ & $11 \mathrm{bc}$ \\
\hline
\end{tabular}

accordance with previous findings, which show that the mean temperature (within some limitations) usually determines the growth rate of greenhouse plants [5] [6]. The content of volatile oil has been found to be strongly increased when basil is grown at $25^{\circ} \mathrm{C}$ to $30^{\circ} \mathrm{C}$ instead of $15^{\circ} \mathrm{C}$ [11] [12]. Therefore, the flavour and taste of the herbs is increased by increased temperatures, as indicated in the present study. The climate-dependent spiciness of herbs should be further investigated, since this is important for the consumer.

\section{Acknowledgements}

This study was supported by Gjennestad Gardener School and the Norwegian Research Council.

\section{References}

[1] Gibson, J.L., Whipker, B.E. and Cloyd, R. (2000) Success with Container Production of Twelve Herb Species. Horticulture Information Leaflet of North Carolina State University, Department of Horticultural Science, Raleigh, 509.

[2] Lasseigne, F.T., Warren, S.L., Blazich, F.A. and Ranney, T.G. (2007) Day/Night Temperature Affects Growth and Photosynthesis of Cultivated Salvia Taxa. Journal of the American Society for Horticultural Science, 132, 492-500.

[3] Mortensen, L.M. and Gislerød, H.R. (2012) The Effect of High $\mathrm{CO}_{2}$ Concentrations on Diurnal Photosynthesis at High Daytime Temperatures in Small Stands of Cut Roses. European Journal of Horticultural Science, 77, 163-169. 
[4] Hückstädt, A., Mortensen, L.M. and Gislerød, H.R. (2013) The Effect of High Maximum Day Temperatures and Coloured Film Cover on Growth and Morphogenesis of Some Herbs in a $\mathrm{CO}_{2}$ Enriched Atmosphere. European Journal of Horticultural Science, 78, 203-208.

[5] Rijsdijk, A.A. and Vogelezang, J.V.M. (2000) Temperature Integration on a 24-Hour Base: A More Efficient Climate Control Strategy. Acta Horticulturae, 519, 163-170.

[6] Adams, S.R., Valdes, V.M., Langton, F.A. and Hamer, P.J.C. (2011) Reducing Carbon Emissions from Greenhouse Production through Use of Temperature Integration and Alternaive Source of Heat. Acta Horticulturae, 893, 95-101.

[7] Putievsky, E. (1983) Temperature and Daylength Influence on the Growth and Germination of Sweet Basil and Oregano. Journal of Horticultural Science \& Biotechnology, 58, 583-587.

[8] Fraszczak, B. and Knaflewski, M. (2009) Effect of Light Conditions and Temperature on Fresh Yield of Some Spice Plants Grown in Containers. Vegetable Crops Research Bulletin, 71, 59-67. http://dx.doi.org/10.2478/v10032-009-0027-6

[9] Mortensen, L.M. (in press) The Effect of Wide-Range Photosynthetic Active Radiations on Photosynthesis, Growth and Flowering of Rosa sp. and Kalanchoe blossfeldiana. American Journal of Plant Science.

[10] Taub, D.R., Seemann, J.R. and Coleman, J.S. (2000) Growth in Elevated $\mathrm{CO}_{2}$ Protects Photosynthesis against HighTemperature Damage. Plant, Cell and Environment, 23, 649-656. http://dx.doi.org/10.1046/j.1365-3040.2000.00574.x

[11] Chang, X., Alderson, P.G. and Wright, C.J. (2005) Effect of Temperature Integration on the Growth and Volatile Oil Content of Basil (Ocimum basilicum L.). Journal of Horticultural Science \& Biotechnology, 80, 593-598.

[12] Chang, X., Alderson, P.G. and Wright, C.J. (2008) Solar Irradiance Level Alters the Growth of Basil (Ocimum basilicum L.) and Its Content of Volatile Oils. Environmental and Experimental Botany, 63, 216-223. http://dx.doi.org/10.1016/j.envexpbot.2007.10.017 